\title{
ПРЕЦЕДЕНТНІ ФЕНОМЕНИ В СИСТЕМІ НАВЧАННЯ УКРАЇНСЬКОЇ МОВИ ЯК ІНОЗЕМНОЇ
}

\author{
МИРОСЛАВА ШЕВЧЕНКО \\ Київський національний університет імені Тараса Шевченка, Київ - Україна \\ PRECEDENSY W SYSTEMIE NAUCZANIA
JEZYKA UKRAIŃSKIEGO JAKO OBCEGO
}

MIROSŁAWA SZEWCZENKO

Kijowski Uniwersytet Narodowy im. Tarasa Szewczenki, Kijów - Ukraina

STRESZCENIE. Niniejszy artykuł poświęcony jest analize precedensów w systemie nauczania języka ukraińskiego jako obcego. Poruszono aspekt metodologiczny, podjęto probę znalezienia optymalnych sposobów prezentacji tych jednostek, a także uzasadnienia potrzeby stworzenia minimum kulturowego na różnych poziomach znajomości języka ukraińskiego wśród studentów-obcokrajowców.

\section{PRECEDENTIAL PHENOMENA IN THE TEACHING SYSTEM OF UKRAINIAN AS A FOREIGN LANGUAGE \\ MYROSLAVA SHEVCHENKO \\ Taras Shevchenko National University of Kyiv, Kyiv — Ukraine}

ABSTRACT. The article is devoted to consideration of the precedential phenomena in methodological aspect, search of optimal presentation of these units before foreign language speaking audience, argumentation related to the necessity of the creation of language and cultural minimum for different levels of the Ukrainian language skills of a foreign student.

$\mathrm{H}$

авчання іноземців української мови кінцевим результатом має досягнення повноцінної комунікації, точніше, комунікативної взаємодії, аксіомами якої $є$,,забезпечення взаєморозуміння на підставі спільності мови як конвенційного коду; зумовленість комунікативної взаємодії спільним фрагментом тезаурусів комунікантів; умотивованість і цілеспрямованість спілкування 3 боку його учасників як підгрунтя комунікативної взаємодії; регуляторна функція системи правил і норм спілкування (комунікативного кодексу), зумовлених культурою, соціумом, сферою спілкування і їі зразком"”.

Ці засадничі загальнодидактичні принципи покладено в основу сучасної комунікативно-культурної компетенції навчання іноземних мов, серцевиною якої $є$ формування комунікативно-культурної компетенції іноземних студентів, їхньої здатності виступати рівноправними партнерами в міжкультурному спілкуванні з носіями мови. Вивчаючи українську мову, іноземний студент стає безпосереднім учасником міжкультурної комунікації, сходинка за сходинкою проходячи всі етапи акультурації, накопичуючи достатній обсяг фонових знань, що визначають структуру і зміст українського мовлення в його національнокультурній самобутності.

${ }^{1}$ О. Селів ванова, Сучасна лінгвістика: напрями і проблеми, Полтава 2008, с. 602. 
Прикметною ознакою сучасного мовлення (як безпосереднього, так і опосередкованого) стало широке вживання прецедентних феноменів (ПФ) відтворюваних ментально-мовних одиниць, що відображають культурну інтелектуально-емоційну пам'ять певної національно-лінгвальної спільноти, виступаючи складниками й загального, й особистого тезаурусу носіїв мови.

У лінгвістичному плані, зокрема лінгвокультурологічному, ПФ досліджували Д. Багаєва, Ф. Бацевич, Л. Даниленко, Д. Гудков, І. Захарченко, О. Земська, Ю. Караулов, В. Костомаров, В. Красних, О. Найдюк, О. Селіванова, К. Серажим, Г. Слишкін, Ю. Сорокін, А. Супрун, Р. Чорноволено-Ткаченко та інші науковці. У працях українських лінгводидактів їх розглядали серед інших мовних знаків культури - важливих компонентів лінгвокультурологічного підгрунтя викладання української мови іноземцям - Н. Зайченко, О. Паламарчук та Н. Присяжнюк. Тим часом ці культурномарковані одиниці характеризуються низкою важливих ознак, суттєвих і в загальнодидактичному, і в лінгвометодичному планах, що потребує їхнього всебічного й глибокого висвітлення. Це завдання набуває ще більшої актуальності завдяки широкому використанню ПФ не лише в українському художньому й публіцистичному дискурсах, але й у щоденному мовленнєвому спілкуванні (безпосередньому та у сфері соціальних мереж). Однаково важливими завданнями $є$ як теоретичний, так і практичний аспекти розв'язання нагальних для лінгводидактики питань. Щодо останнього, йдеться про визначення мінімуму ПФ, що поряд із фразеологічним та пареміологічним мінімумами має увійти до Програми з української мови як іноземної для рівнів В1-В2 та С1.

Прецедентні феномени є цікавими й водночас складними для сприйняття представниками інших лінгвокультур з огляду на комплекс їхніх формальнозмістових і функціонально-прагматичних ознак, до яких належать інформаційно-пізнавальна значущість; облігаторність; повторюваність у різноманітних дискурсах; значна поширеність; тематична різнорідність (найменування об'єктів й асоціативних лінгвореалій зі сфери літератури, живопису, скульптури, архітектури, музики, народної творчості, національні терміни-поняття, інтернаціональні слова 3 характерними прагматичними значеннями, авторські неологізми); різноманітність формальних засобів, за якими розрізняють ПФ, від лексичних, синтаксичних одиниць до ритмічної організації, граматичних і стилістичних особливостей, специфічних конотацій слів і висловлювань; семантична об'ємність, можливість слугувати замінником усього тексту-джерела чи бути конденсатом його змісту (напр., порівняймо шевченківські хрущі і його ліричну мініатюру Садок вишневий коло хати...).

Безперечну цінність для лінгводидактичного опису ПФ, представлених у ментальному культурно-мовному просторі носіїв української мови, має визначення їхньої сутності Ю. Карауловим, який наголошує на таких ознаках цих культурномаркованих одиниць. Вони: 1) добре відомі всім представникам національної лінгвокультурної спільноти („мають надособистісний характер”); 2) є актуальними в когнітивному (пізнавальному й емоційному) плані; 3) звернення (апеляція) до яких постійно відновлюється в мовленні представників тієї чи іншої національно-культурної спільноти ${ }^{2}$. Прецедентні концептуальні структури на вербальному рівні можуть бути презентовані „ім'ям (онімом), сполукою, висловленням, текстовим фрагментом і цілісним текстом"з.

\footnotetext{
${ }^{2}$ Ю. Н. Караулов, Русский язык и языковая личность, Москва 1987, с. 216.

${ }^{3}$ О. Селіванова, Сучасна лінгвістика: напрями і проблеми, Полтава 2008, с. 287.
} 
Звернення учасників комунікації до ПФ - це своєрідний процес збереження минулого й водночас відкриття нового в старому, накопичення культурних цінностей безвідносно до того, з якої культури вони запозичені. У контексті такої спадковості правомірно говорити також про збереження, розвиток, модифікацію певних мотивів, до яких, без сумніву, належать моральні й філософські проблеми. Реалізуючись у різноманітних текстуальних зв'язках, вони переосмислюються й специфічно відображаються індивідуально-естетичною свідомістю учасників комунікації, сформованою певною національною культурою. Тому надзвичайно важливою $є$ орієнтація „учасників спілкування у прагматичній сутності ПФ, оскільки відсутність такої орієнтації може викликати певний психологічний "дискомфорт" у спілкуванні. Такий психологічний і комунікативний дискомфорт знайомий багатьом у разі нерозуміння натяку (алюзії) адресанта на відомий (але не адресату, особливо іншомовному) художній текст, факт історії, побутовий факт тощо"4.

Для прикладу наведемо уривок тексту з роману П. Загребельного (свого часу його аналізували іноземні студенти-філологи на завершальному етапі навчання) $)^{5}$, „Райдуги купаються в Дніпрі, небо хмарніє від птаства, червоновишневі зорі горять угорі, земля стогне від тяжкості хлібів, громи вигуркочують над посереддю Ріки, і садки вишневі коло хат, і хрущі над вишнями, і червоно устає в небо псалом залізу, а над усім мова гримить, і шепоче, і ніжно лащиться, і бунтується: „О люди, люди небораки...”, i дух рве до бою, і діти просять „моні!”, а матері лебедіють над ними, і мружаться гаї, „леліс, віс, ласкавіє", і небо пахне сміхом".

Звичайно, адекватне декодування глибинного змісту цього уривку (ПФ вжиті в ньому і як пряма цитація, і як алюзія, і як ремінісценція) потребує не лише певного обсягу фонових знань, але й проникнення до способу мислення й світосприйняття, характерного для українців, коли йдеться, зокрема, про мову: ліричність, сердечність, піднесеність, урочистість, до певної міри сентиментальність. Прикметно, що нерідко викладачі української мови як іноземної наштовхуються на парадокс: „тексти, насичені національними реаліями, посиланнями на відоме носієві мови, написані соковитою українською мовою, і здавалося б, призначені саме для їх лінгвокраїнознавчого прочитання, виявляються непридатними для роботи над ними в іншомовній аудиторіі”'“.

Наведений приклад функціонування національно-специфічних ПФ показовий і щодо критеріїв формування культурологічного мінімуму для навчання іноземців, критерію авторства зокрема, й щодо психологічної структури фонових знань носіїв української мови. Критерій авторства визначає зв'язок аналізованих одиниць 3 текстом-джерелом: твори українського фольклору та літератури, кіно, живопису, масової культури (популярні пісні, висловлювання відомих діячів культури, політики тощо, комерційна та соціальна реклама).

На сьогодні, як не прикро про це говорити, ми не маємо фундаментального лінгвокраїнознавчого словника „Україна” (на кшталт відомих видань „Великобританія”, „США”, „Росія”, „Німеччина” та ін.), який міг би стати основою відбору ПФ до навчальних мінімумів української мови як іноземної. До речі, українські лінгводидакти (і практики, й теоретики) ще на початку 90-х років

${ }^{4}$ Ф. С. Бацев ич, Нариси з лінгвістичної прагматики, Львів 2010, с. 140.

${ }^{5}$ Н. Зайченко, О. Паламарчук, Функиіонування мовних знаків культури в художньому тексті як лінгводидактична проблема в 2 m., Матер. Міжнар. славіст. конф. пам'яті проф. К. К. Трофимовича (1-3 квітня 1998 р.), т. 1, Львів 1998, с. 419.

${ }^{6}$ Там само, с. 419. 
минулого століття усвідомлювали необхідність здійснення такого проекту зусиллями фахівців різних галузей знань ${ }^{7}$. Надзвичайно цінною у цьому напрямку є праця В. Жайворонка Знаки національної етнокультури: словник-довідник, у якій автор наводить не лише „лексикографічний опис мовних одиниць, семантика яких має зазвичай глибинні етнокультурні нашарування..., а й супроводжує їх різноманітними фольклорними контекстами, характерними цитатами 3 класичної художньої та літописної літератури, Бібілії, „Слова о полку Ігоревім" та ін."8.

Доцільно в цьому зв'язку наголосити, що створення культурологічного мінімуму для різних рівнів навчання української мови як іноземної - важливий, необхідний, але лише один аспект порушеної в цій розвідці проблеми. Другий аспект пов'язаний із власне методичними питаннями — включенням ПФ, поряд 3 іншими культурномаркованими одиницями, до навчального процесу зі студентами-іноземцями.

Методологічною основою такої роботи є, по-перше, визнання нерозривної єдності мови й культури, „мови мислі” й „мови почуттів” i, по-друге, органічне поєднання в колективній свідомості носіїв будь-якої мови загальнолюдських, регіональних (в т. ч. релігійно-культурної традиції) і національно-специфічних культурних феноменів. У процесі навчання іншомовних студентів української мови має відбуватися не просто оволодіння новим мовним кодом, але й новим (рівень новизни визначається належністю студента до конкретної лінгвокультурної спільноти) культурним кодом. Не слід, проте, забувати, що міжкультурна мовна особистість формується внаслідок взаємодії української культурномовної традиції, як національно-специфічного ментального простору, з ментальним простором інших культурно-мовних традицій. Саме ця обставина уможливлює реалізацію лінгвокраїнознавчого аспекту викладання української мови: відштовхуючись від загальнолюдського в мовній картині світу, розкривати іномовцеві закодовану у вербальній площині цільової (у цьому разі - української) мови національно-самобутню складову їі культури.

ПФ, подібно до інших мовних знаків культури, $є$ „живими організмами”, як потенційні одиниці мови, вони знаходять своє життя в різних стилях мовлення й ситуаціях спілкування. Чи не найвпливовішим на сучасному етапі засобом спілкування є інтернет-комунікація. Мовна свідомість масового споживача інформації з інтернет-ресурсу формується значною мірою так званою „масовою культурою" з їі новою прецедентністю. Проте в ній залишається місце й традиційним ПФ української культури, зокрема пов'язаним із творчістю Тараса Шевченка. Наприклад, контексти вживання відомих поетових рядків „Учітесь, читайте, і чужому научайтесь, й свого не цурайтесь...” дуже різноманітні, зокрема таку назву отримала наукова рубрика, присвячена 115-й річниці відкриття Х-променів Вільгельмом Конрадом Рентгеном. У статті рубрики автори наголосили, що першим у плеяді дослідників опромінення повинне стояти ім'я українського вченого Івана Павловича Пулюя, оскільки саме він першим звернув увагу на це явище. „Учітесь, читайте...” називається портал, на якому публікують тексти наказів Міністерства праці, Міністерства освіти та науки України, які стосуються роботи кадрово-консалтингової компанії „Еліт персона”. Користувачами Живого журналу створено декілька просвітницьких та ін-

${ }^{7}$ Н. Зайченко, Н. Присяжнюк, Питання українознавства в аспекті лінгводидактики слов 'янських мов, [w:] „Krakowskie Zeszyty Ukrainoznawcze”, Kraków 1994-1995, т. III-IV, s. $225-231$.

${ }^{8}$ В. В. Жай воронок, Знаки украӥнської етнокультури, Словник-довідник, Київ 2006, с. 3-4. 
формаційних блогів під загальною назвою „Учітесь, читайте, і чужого научайтесь...”, які надають інформацію, що стосується різних сфер життя в Україні та

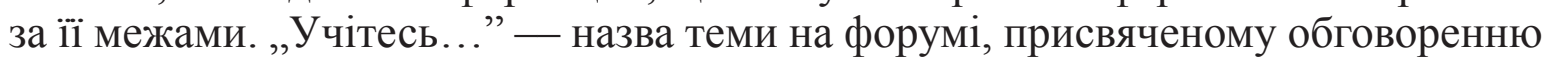
„експансії” нетрадиційних для української культури свят.

Отже, бачимо, що ПФ є одночасно одиницею когнітивного й мотиваційного рівнів мовної особистості, з одного боку, вона позначає певні знання про світ, виконуючи номінативну функцію, а з іншого, — ця одиниця бере участь у формуванні ціннісного універсаму, часто слугує засобом оцінки й мотивації тих чи тих життєвих явищ.

Певна річ, вибір форм, прийомів роботи з подібними текстами залежить від цілої низки позамовних факторів - контингенту студентів, профілю навчання, рівня мовної підготовки, тому зупинимося лише на загальних рекомендаціях.

Включення ПФ до навчального процесу в іншомовній аудиторії вимагає певної послідовності дій, спрямованих на формування „чуття” мови, навичок „упізнавання” й розуміння інтертекстуальних одиниць, а відтак і правильного розуміння усього змісту висловлювання. Опрацювання прецедентних феноменів як одиниць із національно-культурним забарвленням доцільно супроводжувати лінгвокраїнознавчим (ширше - лінгвокультурологічним) коментарем, що має на меті „висвітлення” змісту, конотацій, екстралінгвістичного наповнення ПФ. Для розкодування цих одиниць необхідно здійснити такі кроки: а) представити ПФ іномовцеві; б) пояснити його значення; в) ознайомити з текстомджерелом чи описати ситуацію-джерело; г) пояснити можливі трансформації, яких він зазнав у новому вживанні; д) ужити його в типовій ситуації; е) запропонувати вправи, спрямовані на його впізнавання й запам'ятовування.

Ми порушили лише частину питань, дотичних до загальної й багатоаспектної проблеми лінгвокультурологічного підгрунтя викладання української мови іноземцям. Актуальними для дослідження залишаються й такі аспекти, як визначення мінімального рівня культурознавчої компетенції іншомовних студентів за професійним спрямуванням їхнього навчання, етнопсихологічними особливостями, національно-культурною традицією, ступенем близькості рідної й української культур. 